\title{
Radiation Induced DNA Damage
}

National Cancer Institute

\section{Source}

National Cancer Institute. Radiation Induced DNA Damage. NCI Thesaurus. Code C18754.

Damage to DNA caused by ionizing radiation. Can cause base change mutations or strand breakage. 